
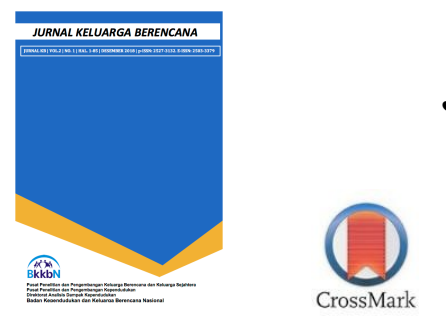

Jurnal Keluarga Berencana

e-ISSN : 2503-3379

p-ISSN : 2527-3132

\title{
PEMETAAN PRILAKU PENGGUNAAN MEDIA INFORMASI DALAM MENGAKSES INFORMASI KESEHATAN REPRODUKSI DI KALANGAN PELAJAR DI JAWA BARAT
}

\author{
Susanne Dida ${ }^{1}$, Syauqy Lukman ${ }^{2}$, Sukarno $^{3}$, Feliza Herison ${ }^{4}$, Centurion Chandratama \\ Priyatna $^{5}$, \\ Arif Rifqi Zaidan ${ }^{6}$, Titut Yuli Prihyugiarto ${ }^{7}$ \\ 1, 2, 4, 5, 6 Universitas Padjadjaran, Fakultas Ilmu Komunikasi \\ ${ }^{3,7}$ Badan Kependudukan dan Keluarga Berencana Nasional \\ ${ }^{1}$ susanne.dida@unpad.ac.id, ${ }^{2}$ syauqy.lukman@unpad.ac.id, ${ }^{3}$ lararashida@gamil.com, \\ ${ }^{4}$ felizaherizon@yahoo.co.id, ${ }^{5}$ centurion.priyatna@gmail.com, ${ }^{6}$ arif.zaidan@bkkbn.go.id, ${ }^{7}$ pakyugi@gmail.com
}

Diterima 27 Januari 2019; diterima dalam bentuk revisi 17 April 2019; diterima 1 October 2019 diterbitkan online 20 Desember 2019

\begin{abstract}
ABSTRAK
Penelitian ini bertujuan untuk (a) mengetahui dan kemudian menjabarkan perilaku penggunaan media informasi di kalangan remaja dalam mencari informasi tentang kesehatan reproduksi; serta (b) perilaku penggunaan internetnya. Penelitian ini menggunakan metode deskriptif dengan populasi remaja tahun pertama hingga keempat dengan rentang umur 18 hingga 24 tahun yang berada di Jawa Barat. Penggumpulan data akan dilakukan melalui angket, wawancara dan observasi. Tipe penelitian ini adalah penelitian deskriptif dengan data kualitatif dan kuantitatif yang dilakukan dengan tujuan menggambarkan atau mendeskripsikan obyek dan fenomena yang berkaitan dengan komunikasi kesehatan, khususnya seputar informasi kesehatan reproduksi di kalangan remaja dengan tujuan untuk memetakan pola, prilaku penggunaan media informasi di kalangan remaja di Jawa Barat. Hasil dari penelitian menunjukkan bahwa platform media informasi yang banyak diakses di kalangan remaja adalah melalui media sosial, paling tinggi instagram dan twitter sedangkan paling rendah koran kemudian diikuti radio. Metode penyampaian pesan dengan infografis dan meme dirasa paling efektif disampaikan melalui media sosial, ini menjadi sesuatu yang perlu diperhatikan dalam mengemas pesan-pesan kesehatan reproduksi untuk remaja, baik oleh BKKBN, maupun pihak-pihak lain yang berkepentingan.
\end{abstract}

(C) 2019 Pusat Penelitian Kependudukan, Keluarga Berencana dan Keluarga Sejahtera - Badan Kependudukan dan Keluarga Berencana Nasional (BKKBN). Ini adalah artikel akses terbuka di bawah lisensi CC BY-NC-SA (https://creativecommons.org/licenses/by-nc-sa/4.0/) 


\section{Pendahuluan}

Prilaku seks pranikah di kalangan anak muda, adalah fenomena yang seringkali ditinjau sebagai permasalahan sosial yang kritikal oleh sebagian besar masyarakat. Sikap pasangan pranikah yang permisif terhadap perilaku seksual pranikah terlihat dari bentuk perilaku seksual yang mereka lakukan.

Berdasarkan Data Badan Koordinasi dan Keluarga Berencana Nasional (BKKBN) tahun 2010 yang dikutip oleh Murni Manurung pada website BKKBN Jawa Barat, $51 \%$ remaja di Jabodetabek telah melakukan seks sebelum menikah. Hasil Survei DKT Indonesia tahun 2005 juga menunjukkan bahwa remaja di beberapa wilayah Indonesia telah melakukan seks sebelum menikah, diantaranya Surabaya 54\%, di Bandung 47\% dan di Medan 52\%. Sementara itu, hasil Survei SKKRI TAHUN 202/2003, bahwa remaja memiliki teman yang pernah berhubungan seksual dimulai dari usia 14-19 tahun, dengan wanita $34,7 \%$ dan pria $30,9 \%{ }^{1}$.

Di kota Bandung sendiri, lebih dari setengah jumlah remaja atau tepatnya 56\% sudah melakukan perilaku seksual intercourse pranikah. Data ini diperoleh berdasarkan survei yang dilakukan oleh Perkumpulan Keluarga Berencana Indonesia (PKBI) Jabar pada bulan Juni 2008 di setiap kecamatan dengan sampel 100 orang remaja berusia 15-24 (13/08/08. Harian Pagi Tribun Jabar).

Masalah perilaku seksual pranikah sudah ada dari beberapa tahun yang lalu dan kasus tersebut terus meningkat setiap tahunnya. Hal ini membuat pemerintah Republik Indonesia mengeluarkan kebijakan pada tahun 1998, melalui Surat Keputusan Menteri Kesehatan Nomor 433/MENKES/SK/V/1998 tentang Komisi Kesehatan Reproduksi yang membentuk sebuah Komisi Kesehatan Reproduksi yang terdiri atas empat Kelompok Kerja (Pokja), salah satunya yaitu Pokja Kesehatan Reproduksi Remaja (PKRR). Dalam artikel di media liputan6

\footnotetext{
${ }^{1}$ Murni Manurung, "membangun Remaja Jawa Barat yang bebas dari masalah seksualitas, Napza, dan HIV/AIDS", http://jabar.bkkbn.go.id/ViewArtikel.aspx?ArtikelID= 586

C)2018 - BKKBN All rights reserved
}

yang mengutip pernyataan dari Kepala BKKBN Pada tahun 2011 tentang data riset BKKBN pada 2010, hasil kajian tersebut menunjukkan, 54 persen remaja di wilayah Jakarta, Bogor, Depok, Tanggerang dan Bekasi atau Jabodetabek telah melakukan hubungan seksual pranikah ${ }^{2}$.

Kemajuan dan keberhasilan suatu negara dapat dilihat dari kualitas remaja di negara tersebut. Remaja menurut Santrock (2003) adalah masa transisi dari masa anak-anak ke masa dewasa awal, dimulai kira-kira usia 12 tahun sampai 15 tahun dan berakhir diusia 18 tahun sampai 22 tahun. Remaja merupakan masa penting yang akan dialami oleh setiap manusia, perlu pengawasan dan pendidikan yang baik agar dihasilkan generasi penerus bangsa yang berkualitas untuk melanjutkan pembangunan suatu negara. Berdasarkan data sensus penduduk yang dilakukan oleh Badan Pusat Statistik tahun 2010, Indonesia memiliki jumlah remaja usia 10-24 tahun yang cukup banyak yaitu sebesar 63.367.920 jiwa atau 26.67 persen dari 237.6 juta jiwa jumlah penduduk total Indonesia. Melihat jumlahnya yang cukup banyak, maka perlu dilakukan pengontrolan dan perhatian terhadap mereka, karena usia tersebut merupakan usia pencarian jati diri. Mereka sangat berisiko terhadap masalah-masalah penyimpangan perilaku yang berkaitan dengan kesehatan seperti perilaku seksual pranikah, Napza, HIV/AIDS, dan Aborsi.

Perilaku seksual pranikah menurut Sarwono (2010) adalah tingkah laku yang berhubungan dengan dorongan seksual bersama lawan jenis maupun sesama jenis yang dilakukan sebelum adanya tali perkawinan yang sah baik secara hukum maupun agama. Perilaku seksual pranikah yang dilakukan oleh remaja dapat memicu permasalahan baru yang akan dihadapi oleh remaja dan lingkungannya seperti aborsi, penularan penyakit seksual menular, HIV/AIDS, pelacuran dan tindakan-tindakan asusila jika dibiarkan terus menerus. Mengutip artikel Kepala BKKBN Jabar pada tahun 2009 dalam website resmi BKKBN Jawa Barat tentang aborsi, kasus aborsi di Indonesia mencapai 2.4 juta jiwa per tahun.

\footnotetext{
${ }^{2}$ https://www.liputan6.com/news/read/308777/bkkbn51-persen-remaja-jabotabek-tidak-perawan
} 
Artikel tersebut mengutip penelitian lembaga Demografi Fakultas Ekonomi Universitas Indonesia tahun 2000 yang melaporkan bahwa kejadian aborsi diperkirakan 2,4 juta per tahun dan $700-800$ ribu diantaranya dilakukan oleh kalangan remaja (BLS LD-FE UI 2000) $)^{3}$. Selain itu, menurut data Pusdatin Kemenkes, total kasus HIV/AIDS di Indonesia yang dilaporkan pada satu Januari sampai tiga puluh Juni 2012 tercatat sebanyak 9.883 kasus HIV dan 2.224 kasus AIDS, dengan 45 persen di antaranya diderita oleh remaja. Angka- angka ini memiliki kemungkinan lebih besar jumlahnya di lapangan karena masih banyaknya kasus yang belum teridentifikasi dan kasus baru yang bermunculan ${ }^{4}$.

Mengetahui tentang tingginya risiko yang dapat ditimbulkan dari prilaku seks pranikah yang kurang baik, negara melalui BKKBN membuat SKRRI (Survey Kesehatan Reproduksi Republik Indonesia) dan diperbaharui menjadi Survei Kependudukan, Keluarga Berencana, Kesehatan Reproduksi Remaja dan Pembangunan Keluarga di Kalangan Remaja Indonesia, salah satunya untuk mengetahui tingkat kesadaran remaja akan kesehatan reproduksi dan memasukannya dalam program KKBPK (Kependudukan dan KB Pembangunan Keluarga).

Salah satu program yang dilakukan BKKBN dalam melakukan diseminasi informasi kesehatan melalu sejumlah media massa dengan berbagai metode penyampaian informasi, baik dengan menggunakan iklan, endorsement, sponsorship acara, dll. Aktifitas yang dilakukan oleh BKKBN adalah menggunakan media above the line (media lini atas), seperti iklan di TV, koran, radio, kemasan acara siar, dll. Alternatif lainnya adalah dengan menggunakan media below the line (media lini bawah), yaitu

\footnotetext{
${ }^{3}$ Rukman Heryana, Aborsi dalam perspektif kependudukan. 4 Juli 2009.

http://jabar.bkkbn.go.id/Lists/Artikel/DispForm.aspx?I $\mathrm{D}=29 \&$ Content TypeId=0x01003DCABABC04B7084 595DA364423DE7897

${ }^{4}$ Infodatin Pusat Data dan Informasi Kementrian Kesehatan RI tentang situasi dan analisis HIV AIDS. http://www.depkes.go.id/resources/download/pusdatin /infodatin/Infodatin\%20AIDS.pdf
}

melalui sponsorship, kegiatan CSR, sosialisasi secara langsung, dll.

Kajian-kajian komunikasi kesehatan terkait bagaimana pola komunikasi, preferensi media, sikap, dan prilaku komunikasi remaja terkait pesan-pesan kesehatan reproduksi, juga perlu mendapatkan perhatian demi lancarnya proses diseminasi informasi kesehatan reproduksi remaja.

Berdasarkan uraian di atas, maka penelitian ini berusaha memetakan tentang prilaku penggunaan media informasi kesehatan reproduksi yang digunakan oleh remaja. Dalam penelitian yang dilakukan oleh Syuderajat (2014) tentang pola penggunaan media internet yang berhubungan dengan aktifitas seksual, remaja mengakses internet setiap hari minimal satu jam, bahkan ada yang mengakui mengakses internet lebih dari lima jam setiap hari sebesar 20\%. Lalu situs-situs jejaring sosial menjadi kategori situs yang paling sering dibuka $36 \%$. Sebagian besar yaitu $71 \%$ remaja menyatakan pernah mengakses situs porno, hampir setengahnya sebesar 39\% menyatakan pernah mengunduh gambar porno sedangkan video porno sebesar 46. Fakta menarik lainnya adalah sebagian besar remaja menyatakan pernah melakukan aktivitas seksual yaitu sebanyak $81 \%$ dan sebagian besar melakukan aktivitas seksual melibatkan pacar sebesar 66\%, sebagian kecil melibatkan teman $8 \%$, PSK $2 \%$, dan lainnya $8 \%$ yaitu "pecun" (perempuan cumacuma) serta tetangga atau anak tetangga rumah maupun kos/kontrakan. Temuan penting dalam riset tersebut adalah, internet dianggap sebagai media penting yang mempengaruhi aktifitas seksual, baik melalui fasilitas email, chatting, dan video chat/web cam. Sebagian besar remaja berpendapat bahwa tayangan asusila di internet berpengaruh terhadap aktivitas seksual mereka yaitu sebesar $62 \%$.

Sementara itu, Susanto (2013) dalam penelitiannya menemukan bahwa ada hubungan positif yang sangat signifikan antara Sikap terhadap media pornografi dengan perilaku seksual. sikap positif terhadap media pornografi terhadap perilaku seksual pranikah secara umum memberi 
sumbangan sebesar $44 \%$ terhadap perilaku seksual pranikah. Kesimpulan dalam penelitian ini adalah ada hubungan positif yang signifikan antara antara ada hubungan positif antara sikap terhadap media pornografi dengan perilaku seksual pranikah pada remaja. Artinya semakin positif sikap terhadap media pornografi maka semakin tinggi perilaku seksual pranikah pada individu. Sebaliknya individu yang memiliki sikap negatif terhadap media pornografi maka semakin rendah perilaku seksual pranikah pada individu.

\section{Media Informasi}

Media berasal dari bahasa latin "medius" yang berarti pengantar atau perantara. Cangara (2009) mendefinisikan media sebagai alat atau sarana yang digunakan untuk menyampaikan pesan dari komunikator kepada khalayak. Media digolongkan kedalam empat macam yaitu media antar pribadi, media kelompok, media publik dan media massa. Rogers (1986) dalam Bungin (2009) menyatakan bahwa dalam hubungan komunikasi di masyarakat, dikenal empat era komunikasi. Era komunikasi yang dimaksud yaitu: era tulis, era media cetak, era media telekomunikasi dan era media komunikasi interaktif. Dalam era terakhir media komunikasi interaktif dikenal media komputer, internet, videotext, teleconferencing, tv kabel dan sebagainya.

Sayling Wen (2002) dalam Bungin (2009) membagi media menjadi tiga bagian yaitu media komunikasi antar pribadi, media penyimpanan dan media transmisi. Media komunikasi antar pribadi dikategorikan oleh Wen menjadi enam media yaitu suara, grafik, teks, musik, animasi dan video.

Hernandez (2007) menyatakan bahwa media massa yang sering digunakan oleh masyarakat saat ini terutama remaja yaitu televisi, internet, musik, radio, dan majalah. Sama halnya dengan Hernandez (2007), Brown et al. (2006) menyatakan bahwa media yang sering digunakan oleh remaja adalah media massa seperti televisi, film, musik, dan majalah. Media menjadi faktor kuat dalam mempengaruhi perilaku seksual remaja.

\section{Komunikasi Kesehatan}

Komunikasi kesehatan yaitu proses penyampaian pesan kesehatan oleh komunikator melalui saluran/media tertentu pada komunikan dengan tujuan yang mengarah pada keadaan sehat, baik secara fisik, mental maupun sosial. Komunikasi itu sendiri adalah pertukaran pesan verbal maupun nonverbal antara si pengirim dengan si penerima pesan, sedangkan kesehatan memiliki pengertian keadaan (status) sehat, baik secara fisik, mental maupun sosial.

Adapun jenis-jenis komunikasi yaitu komunikasi verbal (melalui kata-kata) dan non verbal (melalui bahasa tubuh). Namun berdasarkan jenis yang lain komunikasi terbagibagi kembali menjadi komunikasi langsung (tanpa menggunakan alat), komunikasi tidak langsung (menggunakan alat), komunikasi massa (kelompok orang dengan jumlah yang besar), komunikasi kelompok (sekelompok orang yang umumnya bisa dihitung), komunikasi perorangan (tatap muka), komunikasi satu arah (tidak mempunyai kesempatan memberikan umpan balik), komunikasi timbal balik (memberikan umpan balik).

\section{Kesehatan Reproduksi}

Istilah reproduksi berasal dari kata "re" yang artinya kembali dan kata produksi yang artinya membuat atau menghasilkan. Jadi istilah reproduksi mempunyai arti suatu proses kehidupan manusia dalam menghasilkan keturunan demi kelestarian hidupnya. Sedangkan yang disebut organ reproduksi adalah alat tubuh yang berfungsi untuk reproduksi manusia.

Menurut BKKBN, (2010), defenisi kesehatan reproduksi adalah kesehatan secara fisik, mental, dan kesejahteraan sosial secara utuh pada semua hal yang berhubungan dengan sistem dan fungsi serta proses reproduksi dan bukan hanya kondisi yang bebas dari penyakit dan kecacatan.

Menurut ICPD, International Conference on Population and Development (1994) kesehatan reproduksi adalah sebagai hasil akhir keadaan sehat sejahtera secara fisik, mental, dan sosial dan tidak hanya bebas dari penyakit atau kecacatan dalam segala hal yang terkait dengan sistem, fungsi serta proses reproduksi.

Menurut Depkes RI (2000) kesehatan reproduksi adalah suatu keadaan sehat secara menyeluruh mencakup fisik, mental dan kehidupan sosial yang berkaitan dengan alat, fungsi serta proses reproduksi yang pemikiran kesehatan reproduksi bukannya kondisi yang bebas dari penyakit melainkan bagaimana seseorang dapat memiliki kehidupan seksual yang aman dan memuaskan sebelum dan sesudah menikah..

Maka dapat disimpulkan bahwa kesehatan reproduksi adalah keadaan sehat secara menyeluruh mencakup fisik, mental dan kehidupan sosial,yang berkaitan dengan 
alat,fungsi serta proses reproduksi. Dengan demikian kesehatan reproduksi bukan hanya kondisi bebas dari penyakit,melainkan bagaimana seseorang dapat memiliki kehidupan seksual yang aman dan memuaskan sebelum menikah dan sesudah menikah.

\section{Remaja}

Berdasarkan data sensus penduduk yang dilakukan oleh Badan Pusat Statistik tahun 2010, Indonesia memiliki jumlah remaja usia 10-24 tahun yang cukup banyak yaitu sebesar 63.367.920 jiwa atau 26.67 persen dari 237.6 juta jiwa jumlah penduduk total Indonesia. Istilah remaja yang dikenal dalam bahasa inggris "adolescence" berasal dari bahasa latin "adolescere" (kata benda, adolescence yang berarti remaja) yang berarti tumbuh menjadi dewasa atau dalam perkembangan menjadi dewasa. Monks (2002) mendefinisikan remaja sebagai suatu fase perkembangan antara masa kanak-kanak dan masa dewasa, berlangsung antara usia 12 sampai 21 tahun. Sarwono (2010) menyatakan bahwa masa remaja dikenal sebagai suatu tahap perkembangan fisik dimana alat kelamin manusia mencapai puncak kematangan. Rentang usia remaja menurut sarwono berada pada usia 15-24 tahun. Hurlock (2004) menjelaskan remaja sebagai masa perkembangan seksual, perkembangan tersebut ditandai oleh datangnya haid pertama atau menarche pada remaja perempuan yang terjadi pada usia 11 tahun dan noctural emission (wet dream atau mimpi basah) yakni pengeluaran sperma cairan yang antara lain berisikan seks kelamin laki-laki, pada remaja laki-laki yang terjadi pada usia 1314 tahun. Masa remaja terbagi menjadi tiga periode yaitu masa remaja awal usia 12-15 tahun, masa remaja pertengahan usia 15-18 tahun, dan masa remaja akhir usia 18-21 tahun.

Serupa dengan Monks, Gunarsa dan Gunarsa (2003) menyatakan bahwa masa remaja sebagai masa peralihan dari masa kanak-kanak ke masa dewasa, meliputi semua perkembangan yang dialami untuk persiapan memasuki masa dewasa. Semua aspek perkembangan dalam masa remaja secara global berlangsung antara umur 12-21 tahun, dengan pembagian periode usia menjadi 12-15 tahun masa remaja awal, 16-18 tahun masa remaja pertengahan dan 19-21 tahun adalah masa remaja akhir.

Santrock (2007) menyatakan bahwa bersamaan dengan berkembangnya aspek kognitif pada masa remaja, sering muncul perbedaan pendapat antara remaja dengan orang tuanya atau orang dewasa lainnya. Mereka tidak lagi memandang orang tua sebagai sosok manusia yang mengetahui segalanya, sehingga banyak orang berpikir bahwa masa remaja merupakan masa yang penuh dengan pertentangan dan menolak nilai-nilai yang telah ditetapkan oleh orang tuanya. Erikson dalam Santrock (2007) menyatakan bahwa pada masa remaja, remaja akan mencermati siapa dirinya, bagaimanakah dirinya, dan arah kehidupan mereka. Pertanyaan mengenai identitas ini akan muncul selama rentang kehidupan remajanya, ketika mereka mulai menyadari mereka akan bertanggung jawab terhadap diri mereka sendiri dan kehidupan mereka, remaja mulai mencari kehidupan seperti apa yang akan mereka jalani. Selain itu, Gunarsa dan Gunarsa (2003) menyebutkan beberapa karakteristik remaja, yaitu: (1) keadaan emosi yang labil, (2) sikap menentang orang tua maupun orang dewasa lainnya, (3) pertentangan dalam dirinya menjadi sebab pertentangan dengan orang tuanya, (4) eksperimentasi atau keinginan yang besar dari remaja untuk melakukan kegiatan orang dewasa yang dapat ditampung melalui saluran ilmu pengetahuan, (5) eksplorasi atau keinginan untuk menjelajahi lingkungan alam sekitar yang sering disalurkan melalui penjelajahan atau petualangan, (6) banyaknya fantasi atau khayalan dan bualan, dan (7) kecenderungan membentuk kelompok dan melakukan kegiatan berkelompok.

\section{Kerangka Teoretik \\ Teori Uses and Gratifications}

Teori Uses and Gratifications meripakan teori efek komunikasi massa yang berfokus pada khalayak yang aktif memilih pesan media sesuai dengan kebutuhannya. Teori tersebut dikenal dengan asumsi bahwa khalayak aktif dan penggunaan media adalah bertujuan untuk ditonjolkan. Hal ini dikarenakan, setiap individu memiliki derajat aktivitas dalam pemanfaatan media mereka.

\section{Tahap Perkembangan Teori Uses and Gratifications}

Teori Uses and Gratifications merupakan perpanjangan dari teori kebutuhan dan motivasi yang dikembangkan Abraham Maslow pada yang mengemukakan bahwa manusia secara aktif mencari pemuasan kebutuhannya mulai lebih konkrit sampai kepada hal-hal yang bersifat abstrak. Maslow (1954) kemudian membagi kebutuhan manusia kedalam bentuk piramida yang berkembang dalam suatu urutan hirarki dengan kebutuhan fisiologi.

\section{Asumsi Teori Uses and Gratifications}


Teori Uses and Gratifications memberikan kerangka piker untuk memahami kapan dan bagaimana individu mengkonsumsi produkproduk media menjadi lebih atau kurang aktif dan berdampak pada meningkatnya atau menurunnya keterlibatan. Beberapa asumsi Teori Uses and Gratifications yang dikemukakan oleh penemu dalam pendekatan ini yaitu Katz, Blimer dan Gurevitch (1973), bahwa terdapat lima asumsi dasar dalam Teori Uses and Gratifications yaitu : 1). Khalayak adalah aktif dan menggunakan media adalah bertujuan. 2). Inisiatif atas keterlibatan pemuasan kebutuhan terhadap pemilihan media tertentu berada ditangan khalayak. 3). Media dan sumber-sumber lain bersama-sama memenuhi kebutuhan khalayak. 4). Orang-orang memiliki cukup kesadaran atas penggunaan media, ketertarikan dan motif. Hal ini yang membuat para peneliti mendapatkan gambaran lebih akurat atas penggunaan media tersebut. 5). Penilaian terhadap isi media hanya dapat dilakukan oleh khalayak itu sendiri.

\section{Konsep Khalayak Aktif}

Mark Levy dan Sven Windahl (1984) memberikan gambaran terhadap konsep khalayak aktif yaiitu adanya rasa suka rela dan orientasi yang selektif dari khalayak terhadap proses komunikasi. Selanjutnya Jay G Blumer (1979) mengemukakan beberapa aktifitas khalayak dimana konsumsi media akan terjadi yaitu : 1). Utility. Media mempunyai kegunaan dan manusia dapat menempatkan media pada kegunaan tersebut. 2). Intentionality. Terjadi pada saat motivasi utama manusia menentukan konsumsi dari isi media mereka. 3). Selectifity. Penggunaan media merupakan refleksi dari ketertarikan dan preferensi mereka. 4). Imperviouses to influence. Khalayak membangun makna mereka atas isi media dan makna tersebut mempengaruhi apa yang dipikirkan dan lakukan.

\section{Preferensi Media}

Menurut Doris Grober dalam Vivian (2008) preferensi media umumnya meminta pengguna media untuk mengurutkan media mana yang paling disukai. Secara umum kata preferensi diartikan sebagai pilihan utama, sehingga kata preferensi media dapat diartikan media pilihan utama. Penggunaan kata preferensi media lazim digunakan dalam melihat penggunaan media massa oleh khalayak. Media massa saat ini cukup banyak dan bervariasi, sehingga masyarakat menentukan pilihan media yang paling disukai untuk digunkan sesuai tujuannya. Dalam konteks penelitian ini, preferensi media yang dimaksud adalah pilihan-pilihan media komunikasi kesehatan reproduksi remaja di Jawa Barat.

\section{Sikap terhadap media}

Menurut Berkowitz dalam Azwar (2013:4) sikap merupakan suatu bentuk evaluasi atau reaksi perasaan. Sikap seseorang terhadap suatu objek adalah perasaan mendukung atau memihak maupun perasaan tidak mendukung atau tidak memihak pada objek tersebut. Sedangkan menurut Thurstone dalam Azwar (2013:5) sikap merupakan derajat afek positif atau afek negative terhadap suatu objek psikologis. Menurut La Pierre dalam Azwar (2013:5) sikap adalah respons terhadap stimuli sosial yang telah terkondisikan. Sedangkan menurut Secord Backman dalam Saiffudin (2013:5) mendefinisikan sikap sebagai keteraturan dalam hal perasaan (afeksi), pemikiran (kognisi), dan predisposisi tindakan (konasi) seseorang terhadap suatu aspek di lingkungan sekitarnya.

Sikap terhadap media adalah bagaimana bentuk evaluasi atau reaksi perasaan, yang merupakan derajat positif dan negatif audiens terhadap media komunikasi yang menjadi stimuli sosial audiens. Dalam konteks penelitian ini, adalah media komunikasi kesehatan reproduksi remaja.

\section{Pengetahuan}

Pengetahuan ialah merupakan hasil "tahu" dan ini terjadi setelah orang melakukan penginderaan terhadap suatu obyek tertentu. Penginderaan terjadi melalui panca indera manusia yaitu : indera penglihatan, pendengaran, penciuman, rasa dan raba. Sebagian besar pengetahuan manusia diperoleh melalui mata dan telinga (Notoadmodjo 2003).

Dalam konteks penelitian ini, pengetahuan yang berusaha diketahui dari sampel, adalah pengetahuan kesehatan reproduksi. Pengetahuan diukur dengan sejumlah butir pertanyaan tentang kesehatan reproduksi remaja, yaitu pengetahuan seputar anatomi dan perawatan kesehatan alat reproduksi, pengetahuan tentang kehamilan, penyakit seks menular, dan alat kontrasepsi.

\section{Prilaku penggunaan media}

Perilaku adalah suatu fungsi dari interaksi antara seorang individu dengan lingkungannya. Perilaku manusia menurut Thoha, adalah fungsi dari interaksi antara individu dengan lingkungannya. Perilaku komunikasi sendiri yaitu suatu tindakan atau perilaku komunikasi baik itu berupa verbal ataupun non verbal yang ada pada tingkah laku seseorang. Menurut Kwick dalam Notoatmodjo (2003), perilaku adalah tindakan 
atau perbuatan organisme yang dapat diamati dan bahkan dapat dipelajari.

Prilaku komunikasi merujuk pada kecenderungan individu untuk mengekspresikan perasaan, kebutuhan, dan pemikiran dengan menggunakan pesan tidak langsung serta

\section{METODE}

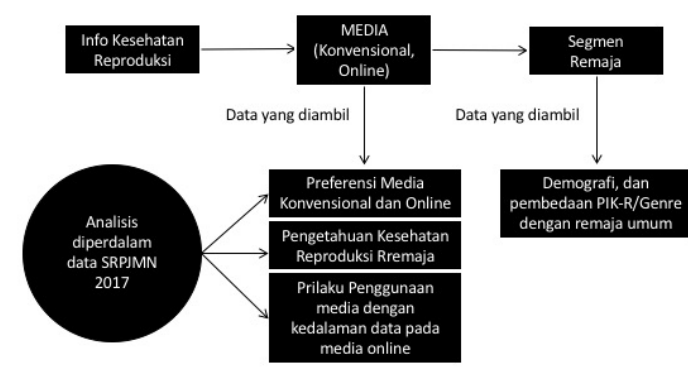

\section{Penelitian Tahap 1 \\ Pengolahan Data Kuantitatif}

Tipe penelitian ini adalah penelitian deskrtiptif dengan data kualitatif dan kuantitatif yang dilakukan dengan tujuan menggambarkan atau mendeskripsikan obyek dan fenomena yang berkaitan dengan komunikasi kesehatan dalam meningkatkan kesadaran remaja mengenai pemeliharaan kesehatan reproduksi.

Metode penelitian deskriptif adalah salah satu metode penelitan yang banyak digunakan pada penelitian yang bertujuan untuk menjelaskan suatu kejadian. Seperti yang dikemukakan oleh Sugiyono (2011) "penelitian desktiptif adalah sebuah penelitian yang bertujuan untuk memberikan atau menjabarkan suatu keadaan atau fenomena yang terjadi saat ini dengan menggunakan prosedur ilmiah untuk menjawab masalah secara aktual". Sedangkan, Sukmadinata (2006) menyatakan bahwa metode penelitian deskriptif adalah sebuah metode yang berusaha mendeskripsikan, menginterpretasikan sesuatu, misalnya kondisi atau hubungan yang ada, pendapat yang berkembang, proses yang sedang berlangsung, akibat atau efek yang terjadi atau tentang kecenderungan yang sedang berlangsung. dampak-dampak prilaku (Ivanov dan Werner, 2010).

Dalam konteks penelitian ini, prilaku penggunaan media adalah bagaimana remaja menggunakan media-media sosial.



\section{Penelitian Tahap 2 \\ Pengolahan data Kualitatif}

Alasan peneliti manggunakan jenis penelitian deskripsi adalah karena dengan penelitian ini mampu memberikan gambaran yang menyeluruh dan jelas terhadap satu situasi dengan situasi sosial yang lain atau dari waktu tertentu dengan waktu yang lain, atau dapat menemukan pola-pola hubungan antara aspek tertentu dengan aspek yang lain, dan dapat menemukan hipotesis dan teori. Dari data deskriptif tersebut diharapkan dapat dihasilkan insight yang baik untuk perumusan hipotesis dan teori.

Adapun jenis data dalam penelitian ini ada dua macam, yaitu jenis data primer dan jenis data sekunder. Yang dimaksudkan dengan jenis data primer adalah jenis data tentang prilaku subyek dalam menggunakan media informasi dalam mencari dan mendapatkan informasi kesehatan reproduksi. Dari data ini, akan diidentifikasi preferensi media subyek dalam mencari informasi kesehatan reproduksi, intensitas penggunaan medianya, serta aspek prilaku lain dalam konteks mendapatkan informasi kesehatan reproduksi.

Data sekunder adalah data yang memuat identitas subyek dan beberapa informasi penting lainnya sebagai referensi triangulasi data. Diantara lain didapatkan dari sumber literatur, riset terdahulu, khususnya dari 
lembaga BKKBN yang berhubungan dengan topik penelitian.

Untuk keabsahan data peneliti menggunakan telaah teknik triangulasi sumber, yaitu penggunaan sumber yang berbeda untuk mengumpulkan data sejenis. Pengumpulan data kualitatif dilakukan dengan cara observasi dan wawancara mendalam. Wawancara dengan beberapa narasumber kunci atau key informants dengan kriteria informan meliputi: 1) Pengamat sosial, khususnya prilaku penggunaan Media; 2) Psikolog/ahli yang mengamati prilaku komunikasi di kalangan remaja/remaja; 3) representasi dari institusi yang memiliki kepentingan seputar masalah informasi kesehatan reproduksi dan penggunaan media yaitu perwakilan dari BKKBN dan Diskominfo Jawa Barat

\section{Instrumen Penelitian}

Instrumen yang digunakan untuk penelitian deskriptif ini adalah berupa kuesioner dengan pertanyaan tertutup, dengan item pertanyan seputar preferensi media, pengetahuan kesehatan reproduksi, sikap terhadap media, dan prilaku komunikasi terhadap media.

Sedangkan untuk data kualitatif, dirumuskan panduan wawancara dengan pertanyaan terbuka untuk wawancara serta pertanyaan pancingan untuk kegiatan Focus Group Discussion. Panduan wawancara dibuat untuk memagari alur wawancara agar tetap focus pada bahasan seputar prilaku penggunaan media informasi dalam pencarian informasi kesehatan reproduksi. Aspek yang diteliti yaitu preferensi media, prilaku penggunaan media, serta beberapa aspek lainnya yang berkaitan dengan topik penelitian.

Teknik pengumpulan data menggunakan bukti multi sumber (triangulasi) artinya teknik pengumpulan data yang bersifat menggabungkan dari berbagai teknik pengumpulan data dan sumber data yang telah ada. Teknik triangulasi berarti peneliti menggunakan teknik pengumpulan data yang berbeda-beda untuk mendapatkan data dari sumber yang sama. Peneliti akan menggunakan observasi partisipatif, wawancara mendalam, FGD, dan dokumentasi untuk sumber data yang sama secara serempak sesuai tahapan yang telah dijelaskan sebelumnya.

\section{Populasi, Sampel, Informan Kunci, dan Partisipan FGD}

Pada tahap pertama, penelitian kuantitatif yang memetakan pengetahuan kespro, preferensi media, dan sikap terhadap media, populasi utama dari penelitian ini adalah remaja. Berdasarkan data, jumlah penduduk remaja Indonesia saat ini mencapai 65 juta jiwa atau sekitar $30 \%$ dari total jumlah penduduk Indonesia. Sementara jumlah penduduk remaja di Provinsi Jawa Barat mencapai 11.358.704 jiwa atau sebesar $26,60 \%$ dari total jumlah penduduk di Jawa Barat.

Menurut Sugiyono (2011: 60) menyatakan bahwa sampling kuota adalah teknik untuk menentukan sampel dari populasi yang mempunyai ciri-ciri tertentu sampai jumlah (kuota) yang diinginkan. Adapun target dari kuisioner ini adalah 1.000 orang sampel yang harus mewakili seluruh daerah kabupaten dan kota di Jawa Barat. Angka 1.000 sampel, dinilai dapat memenuhi keterwakilan populasi remaja di Jawa barat.

Sayangnya, tidak ada data akurat mengenai jumlah penduduk usia remaja berdasarkan masing-masing Kabupaten dan Kota pada data BPS. Untuk itu, peneliti menentukan proporsi sampel berdasarkan proporsi jumlah penduduk Jawa Barat berdasarkan proyeksi jumlah penduduk dari data Biro Pusat Statistik Jawa Barat per Kabupaten Kota pada tabel di bawah ini. Proporsi jumlah penduduk masing-masing Kabupaten/Kota, akan dibagi relatif dengan total penduduk Jawa Barat, lalu prosentasenya akan dikalikan dengan quota sampel yang ditentukan yaitu sebanyak 1.000 sampel.

\section{Penentuan Informan Kunci dan peserta Focus Group Discussion}

Pada tahap kedua penelitian, data kuantitatif pada tahap pertama akan dijadikan rujukan analisis data dengan menggunakan metode interview mendalam dan Focus Group Discussion Tujuan dari penelitian tahap kedua adalah membuat model 
komunikasi/rekomendasi terkait hal-hal penting yang perlu diperhatikan dalam mensosialisasikan informasi kesehatan reproduksi di kalangan remaja. Data akan digunakan berdasarkan analisis kualitatif menggunakan FGD dan in-depth interview dengan stakeholder terkait diseminasi informasi kesehatan reproduksi remaja. Hasil analsis data kualitatif akan dirumuskan menjadi masukan kepada pemerintah khususnya BKKBN mengenai model komunikasi untuk mensosialisasikan informasi kesehatan reproduksi kepada remaja dengan media yang tepat.

Setiap informan kunci dan peserta FGD akan diberikan penjelasan mengenai data kuantitatif yang diperoleh dalam tahap pertama, dan akan menganalisis data tersebut berdasarkan latar belakang/kompetensi masing-masing. Adapun daftar informan kunci dan partisipan FGD dapat dilihat pada tabel transkrip analisis FGD terkait prilaku penggunaan media informasi remaja pada hasil dan pembahasan.

\section{HASIL DAN PEMBAHASAN}

\section{Kuisioner Pengetahuan Kesehatan Reproduksi dan Preferensi Komunikasi Kesehatan Reproduksi}

Kuisioner yang disebar berusaha untuk memetakan pengetahuan sampel seputar Kesehatan Reproduksi dan juga terkait preferensi mereka mengenai pola komunikasi kesehatan reproduksi. Pengukuran pengetahuan, dilakukan dengan cara menguji responden dengan pertanyaan benar dan salah di mana jawaban yang salah akan diberi nilai nol (0) dan jawaban yang benar akan mendapatkan nilai 1 . Sedangkan pengukuran preferensi menggunakan skala likert dengan pembobotan nilai maksimal 5 untuk jawaban yang paling positif, dan nilai minimal 1 untuk jawaban yang paling negative.

Kuisioner pengetahuan kesehatan reproduksi, diukur dengan 10 pertanyaan yang terdiri dari pertanyaan tema-tema pengetahuan kesehatan reproduksi, yaitu pendewasaan usia pernikahan, penyakit seksual menular, alat kontrasepsi, dan kesehatan organ reproduksi, semua item pertanyaan telah diuji validitas dan reliabilitasnya.

Statistics
\begin{tabular}{|l|r|}
\hline \multicolumn{2}{|c|}{ NILAI/SKOR } \\
\multicolumn{1}{|c|}{ Valid } & 1006 \\
Missing & 0 \\
Mean (Rata-rata) & 59.17 \\
Mode (Modus) & 60 \\
Minimum (Nilai terendah) & 20 \\
Maximum (Nilai tertinggi) & 100 \\
\hline
\end{tabular}

Secara umum, memperhatikan nilai total yang diperoleh dari responden terkait pengetahuan kesehatan reproduksi dengan analisis kecenderungan gejala pusat atau central tendency mean 59.17, mode 60, minimum 20, $\max 100$, maka dapat disimpulkan bahwa dari 1006 responden tersebut, pengetahuannya berada di angka menengah cenderung baik, walaupun tidak dapat dikatakan tinggi. Namun jika data antara PIK-R/M dengan remaja 'umum' dipisah, dapat dilihat bahwa kecenderungannya berubah.

\section{Preferensi Komunikasi}

Dalam kuisioner preferensi kuisioner, terdapat 11 item pertanyaan tertutup yang berusaha memetakan preferensi komunikasi dari responden, berusaha untuk melihat kondisi existing pengetahuan responden berdasarkan perspektif mereka sendiri, preferensi terkait penyampaian informasi dari BKKBN, preferensi media berdasarkan bedahan media konvensional, mainstream, dan media baru, juga 4 pertanyaan terbuka terkait preferensi platform komunikasi dan gaya yang disukai. 


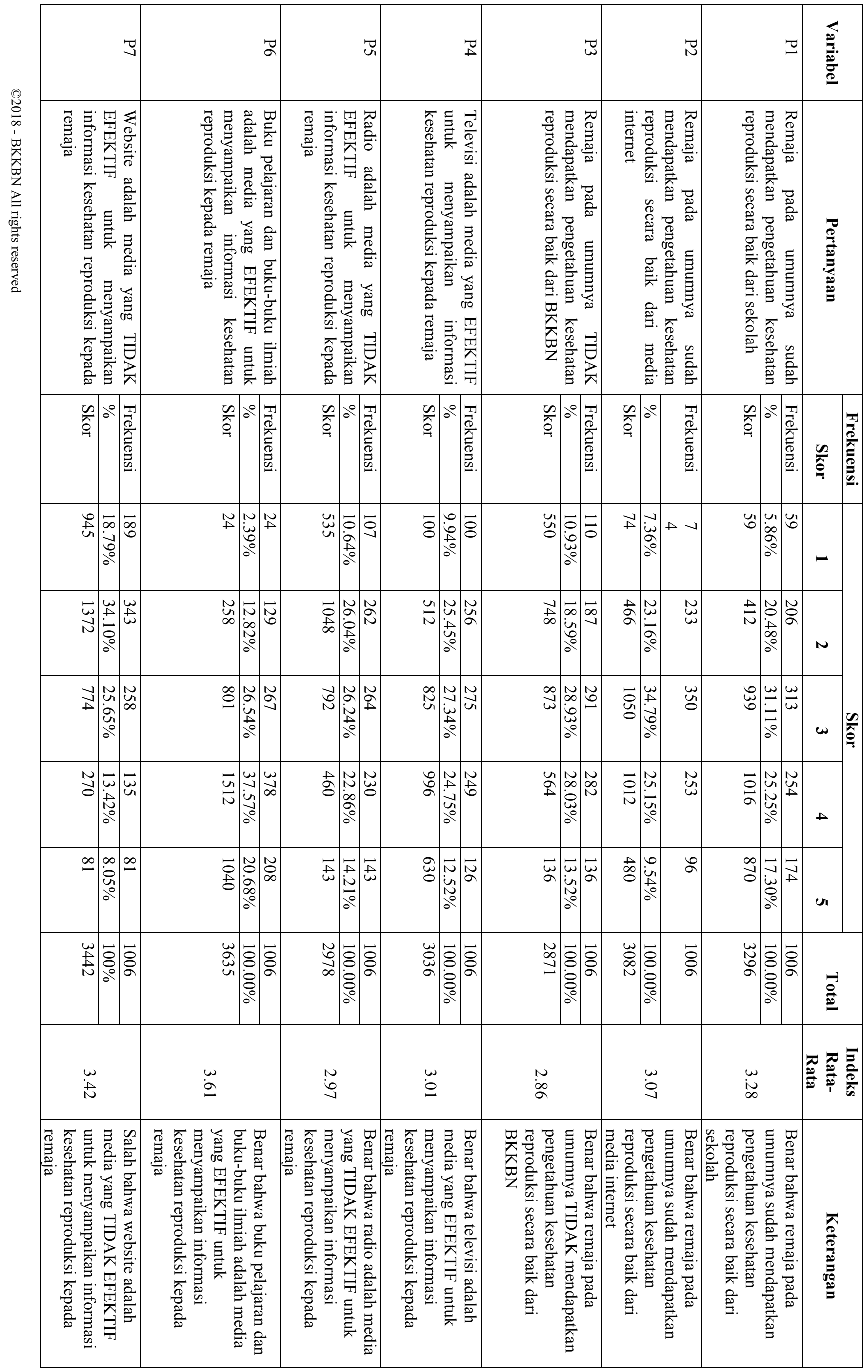


Susanne Dida / Jurnal Keluarga Berencana Vol.4 No.02 (2042) 35-46

\begin{tabular}{|c|c|c|c|c|c|c|c|c|c|c|}
\hline \multirow[t]{3}{*}{ P8 } & \multirow{3}{*}{$\begin{array}{lr}\text { Social Media seperti } & \text { Instagram, } \\
\text { Facebook, Twitter adalah media yang } \\
\text { TIDAK } & \text { EFEKTIF } \\
\text { menyampaikan informasi } & \text { kesehatan } \\
\text { reproduksi kepada remaja } & \end{array}$} & Frekuensi & 290 & 290 & 185 & 146 & 95 & 1006 & \multirow[b]{3}{*}{3.53} & \multirow{3}{*}{$\begin{array}{l}\text { Salah bahwa sosial media seperti } \\
\text { Instagram, Facebook, Twitter } \\
\text { adalah media yang TIDAK } \\
\text { EFEKTIF untuk menyampaikan } \\
\text { informasi kesehatan reproduksi } \\
\text { kepada remaja }\end{array}$} \\
\hline & & $\%$ & $28.83 \%$ & $28.83 \%$ & $18.39 \%$ & $14.51 \%$ & $9.44 \%$ & $100.00 \%$ & & \\
\hline & & Skor & 1450 & 1160 & 555 & 292 & 95 & 3552 & & \\
\hline \multirow[t]{3}{*}{ P9 } & \multirow{3}{*}{$\begin{array}{l}\text { Penggunaan Duta Genre EFEKTIF } \\
\text { untuk mengkomunikasikan info } \\
\text { kesehatan reproduksi kepada remaja } \\
\text { (silakan klik pilihan ke-3 jika Anda } \\
\text { tidak tahu apa itu Duta Genre) }\end{array}$} & Frekuensi & 26 & 39 & 612 & 183 & 146 & 1006 & \multirow[b]{3}{*}{3.39} & \multirow{3}{*}{$\begin{array}{l}\text { Benar bahwa Penggunaan Duta } \\
\text { Genre EFEKTIF untuk } \\
\text { mengkomunikasikan info } \\
\text { kesehatan reproduksi kepada } \\
\text { remaja. }\end{array}$} \\
\hline & & $\%$ & $2.58 \%$ & $3.88 \%$ & $60.83 \%$ & $18.19 \%$ & $14.51 \%$ & $100.00 \%$ & & \\
\hline & & Skor & 26 & 78 & 1836 & 732 & 730 & 3402 & & \\
\hline \multirow[t]{3}{*}{ P10 } & \multirow{3}{*}{$\begin{array}{l}\text { Penggunaan Selebrita (Orang terkenal) } \\
\text { dan figur publik, EFEKTIF untuk } \\
\text { mengkomunikasikan info kesehatan } \\
\text { reproduksi kepada remaja }\end{array}$} & Frekuensi & 37 & 127 & 238 & 424 & 180 & 1006 & & \multirow{3}{*}{$\begin{array}{l}\text { Benar bahwa penggunaan } \\
\text { Selebrita (Orang terkenal) dan } \\
\text { figur publik, EFEKTIF untuk } \\
\text { mengkomunikasikan info } \\
\text { kesehatan reproduksi kepada } \\
\text { remaja }\end{array}$} \\
\hline & & $\%$ & $3.68 \%$ & $12.62 \%$ & $23.66 \%$ & $42.15 \%$ & $17.89 \%$ & $100.00 \%$ & & \\
\hline & & Skor & 37 & 254 & 714 & 1696 & 900 & 3601 & 3.59 & \\
\hline \multirow[t]{3}{*}{ P11 } & \multirow{3}{*}{$\begin{array}{l}\text { Media website genrejabar.or.id akan } \\
\text { EFEKTIF dalam mengkomunikasikan } \\
\text { info kesehatan reproduksi kepada } \\
\text { remaja }\end{array}$} & Frekuensi & 36 & 86 & 408 & 321 & 155 & 1006 & \multirow[b]{3}{*}{3.47} & \multirow{3}{*}{$\begin{array}{l}\text { Benar bahwa media website } \\
\text { genrejabar.or.id akan EFEKTIF } \\
\text { dalam mengkomunikasikan info } \\
\text { kesehatan reproduksi kepada } \\
\text { remaja }\end{array}$} \\
\hline & & $\%$ & $3.58 \%$ & $8.55 \%$ & $40.56 \%$ & $31.91 \%$ & $15.41 \%$ & $100.00 \%$ & & \\
\hline & & Skor & 36 & 172 & 1224 & 1284 & 775 & 3491 & & \\
\hline
\end{tabular}

Notes:

Pertanyaan positif $>3=$ Benar

Pertanyaan negative $>\mathbf{3}=$ Salah

$<3=$ Benar 
Secara umum terkait preferensi komunikasi kesehatan reproduksi dapat disimpulkan beberapa hal berikut ini:

- Benar bahwa remaja pada umumnya sudah mendapatkan pengetahuan kesehatan reproduksi secara baik dari sekolah (indeks 3.28), dengan demikian pengetahuan di sekolah tentang kesehatan reporudksi sudah cukup baik.

- Benar bahwa remaja pada umumnya sudah mendapatkan pengetahuan kesehatan reproduksi secara baik dari media

internet (indeks 3.07), dengan demikian pengetahuan reproduksi dari internet juga sudah cukup baik meskipun idenksnya berada di ambang batas nilai minimun (3) dan perlu digali lebih dalam informasi yang diperoleh sebenarnya seperti apa dari internet terkait kesehatan reproduksi.

- Benar bahwa remaja pada umumnya TIDAK mendapatkan pengetahuan kesehatan reproduksi secara baik dari BKKBN (indeks 2.86), indeks ini menunjukkan bahwa responden merasa belum terpapar informasi kesehatan reproduksi dari BKKBN.

- Benar bahwa televisi adalah media yang EFEKTIF untuk menyampaikan informasi kesehatan reproduksi kepada remaja (indeks 3.01), cukup jelas bahwa TV memang masih dianggap efektif dalam menyampaikan pesan ksehatan reproduksi.

- Benar bahwa radio adalah media yang TIDAK EFEKTIF untuk menyampaikan informasi kesehatan reproduksi kepada remaja (indeks 2.97), cukup jelas bahwa radio dianggap tidak efektif dalam mendiseminasikan informasi kesehatan reproduksi.

- Benar bahwa buku pelajaran dan bukubuku ilmiah adalah media yang EFEKTIF untuk menyampaikan informasi kesehatan reproduksi kepada remaja (indeks 3.61), ini menunjukkan bahwa jika konten kesehatan reproduksi menggunakan buku-buku pelajaran, remaja merasa media tersebut sebagai rujukan yang efektif, bisa menjadi pertimbangan untuk pelengkap kurikulum.

- Salah bahwa website adalah media yang TIDAK EFEKTIF untuk menyampaikan informasi kesehatan reproduksi kepada remaja (indeks 3.42), cukup jelas, website adalah salah satu media daring yang dianggap efektif dalam menyampaikan info kespro.

- Salah bahwa sosial media seperti Instagram, Facebook, Twitter adalah media yang TIDAK EFEKTIF untuk menyampaikan informasi kesehatan reproduksi kepada remaja (indeks 3.52), begitu juga media daring berbasis socmed memang dirasa efektif dalam menyampaikan info kesehatan reproduksi.

- Benar bahwa Penggunaan Duta Genre EFEKTIF untuk mengkomunikasikan info kesehatan reproduksi kepada remaja. (indeks 3.39), menunjukkan bahwa penggunaan duta genre efektif.

- Benar bahwa penggunaan Selebrita (Orang terkenal) dan figur publik, EFEKTIF untuk mengkomunikasikan info kesehatan reproduksi kepada remaja (indeks 3.59)

- Benar bahwa media website genrejabar.or.id akan EFEKTIF dalam mengkomunikasikan info kesehatan reproduksi kepada remaja (indeks 3.47), menunjukkan bahwa web ini sudah menjalankan fungsinya dengan baik untuk mengkomunikasikan info kesehata reproduksi kepada remaja. 
Platform social media mana yang menurut Anda paling tepat dan disukai remaja untuk menyebarkan informasi kesehatan reproduksi?

\begin{tabular}{|ll|r|r|r|l|}
\hline & \multicolumn{1}{|l|}{$\begin{array}{l}\text { Freque } \\
\text { ncy }\end{array}$} & Percent & $\begin{array}{l}\text { Valid } \\
\text { Percent }\end{array}$ & $\begin{array}{l}\text { lumulative } \\
\text { Percent }\end{array}$ \\
\hline Valid & Line & 256 & 25.4 & 25.4 & 25.4 \\
& Whatsapp & 49 & 4.9 & 4.9 & 30.3 \\
Kakao & 2 & .2 & .2 & 30.5 \\
Facebook & 62 & 6.2 & 6.2 & 36.7 \\
Twitter & 31 & 3.1 & 3.1 & 39.8 \\
Instagram & 589 & 58.5 & 58.5 & 98.3 \\
Snapchat & 4 & .4 & .4 & 98.7 \\
Lainnya.. & 13 & 1.3 & 1.3 & 100.0 \\
Total & 1006 & 100.0 & 100.0 & \\
\hline
\end{tabular}

\section{Analisis kuisioner pengetahuan dan preferensi komunikasi kesehatan reproduksi}

Secara umum pengetahuan remaja seputar kesehatan reproduksi ada pada angka 59,4 dengan nilai maksimal 100 . Pengetahuan diukur dengan beberapa pertanyaan seputar pengetahuan tentang alat kontrasepsi, penyakit seksual menular, penundaan usia pernikahan, dan pemberian jarak kehamilan. Angka ini menunjukkan bahwa secara umum pengetahuan remaja yang menjadi sampel populasi secara umum berada di angka menengah. Namun angka menjadi berubah saat karakteristik responden dipisah antara remaja PIR-R/M dengan remaja umum, di mana remaja PIK$\mathrm{R} / \mathrm{M}$ secara umum memiliki tingkat pengetahuan yang sedikit lebih tinggi terkait kesehatan reproduksi. Begitu juga jika memisahkan remaja yang pernah terpapar materi dari BKKBN dengan yang belum terpapar.
Sedangkan pada persepsi remaja terkait media-media yang digunakan BKKBN dalam menyampaikan pesan kesehatan reproduksi dinilai masih kurang baik, dengan penekanan preferensi mereka pada media-media online. Remaja juga merasa bahwa mereka merasa kurang mendapatkan informasi kesehatan reproduksi yang cukup, baik dari BKKBN, sekolah, maupun sumber lainnya.

Platform media yang paling banyak dipilih adalah social media, khususnya Instagram dan Line, sedangkan Koran adalah platform yang paling tidak dipilih oleh responden disusul dengan radio. Metode penyampaian yang dirasa paling efektif oleh responden adalah infografis dan meme, ini menjadi sesuatu yang perlu diperhatikan dalam mengemas pesan-pesan kesehatan reproduksi untuk remaja, baik oleh BKKBN, maupun pihak-pihak lain yang berkepentingan.

\section{Focus Group Discussion}

Tahapan kedua penelitian adalah melakukan FGD dengan mengundang sejumlah narasumber untuk mendiskusikan hasil penelitian tahap pertama dengan sejumlah stakeholder yang memiliki kepentingan seputar issue komunikasi kesehatan reproduksi. Berikut ini adalah matriks yang berisi daftar narasumber FGD yang menjadi peserta kegiatan dan issue seputar komunikasi kesehatan reproduksi remaja yang dikaji dalam FGD tersebut 
Secara garis besar, setelah mendiskusikan temuan penelitian dan para stakeholder berdiskusi tentang issue komunikasi kesehatan reproduksi, maka ditarik kesimpulan antara lain:

-Bagaimana diseminasi informasi kesehatan reproduksi ternyata di BKKBN, Diskominfo, Dinas Kesehatan, dan dinas terkait, tidak ada kerjasama, jadi masingmasing berjalan dengan medianya sendiri (asyik sendiri), masih kurang koordinasi;

-Keberadaan duta Genre (generasi berencana) atau konsultan sebaya (peer group educators), dapat mendorong komunikasi kesehatan reproduksi, walau dapat diakui tidak semua duta genre memiliki kemampuan berkomunikasi dengan baik;

-Walaupun kita menggunakan media social dalam mengkomunikasikan kesehatan reproduksi, media konvensional tetap diperlukan terutama untuk orang tua, maupun orang-orang yang tidak tersentuh media sosial dan internet. Selain itu, di keluarga, setiap orang harus diberikan pemahaman dan adanya keterbukaan antara orang tua dan anak;

-Platform komunikasi perlu disesuaikan dengan karakteristik audiens, juga disesuaikan dengan kemampuan mengakses platform-platform yang digunakan. Penting untuk menggunakan endorser, influencer, blogger, namun perlu juga ada figure-figur inspirator di media social.

-Yang juga disoroti adalah political will dari pemerintah terkait keseriusan mendorong issue ini dalam berbagai lini pemerintahan, juga perlunya ada pembelajaran terhadap ilmu lain yang menunjang juga perlu diterapkan di sekolah.

\section{KESIMPULAN DAN SARAN}

- Dari hasil FGD dan analisis dari kuisioner, dapat disimpulkan bahwa pemahaman informasi kesehatan reproduksi di kalangan remaja masih berada di kisaran menengah, responden anggota $\mathrm{PIK}-\mathrm{R} / \mathrm{M}$ memiliki tingkatan pengetahuan yang lebih baik, begitu juga responden yang pernah terpapar materi dari BKKBN, memiliki tingkatan pengetahuan yang lebih baik ketimbang remaja biasa.
- Persepsi remaja terkait media-media yang digunakan BKKBN dalam menyampaikan pesan kesehatan reproduksi dinilai masih kurang baik, dengan penekanan preferensi mereka pada media-media online. Remaja juga merasa bahwa mereka merasa kurang mendapatkan informasi kesehatan reproduksi yang cukup, baik dari BKKBN, sekolah, maupun sumber lainnya.

- Platform media yang paling banyak dipilih adalah social media, khususnya Instagram dan Line, sedangkan Koran adalah platform yang paling tidak dipilih oleh responden diikuti oleh radio.

- Metode penyampaian pesan yang dirasa paling efektif oleh responden adalah infografis dan meme.

- Diskusi seputar issue komunikasi kesehatan reproduksi banyak menyorot issue kurang kompaknya dinas-dinas terkait dalam mengolah informasi kesehatan reproduksi. Selain itu diskusi tentang pentingnya mengeksplorasi berbagai platform komunikasi, khususnya yang memang disukai oleh remaja, seperti platform social media dengan berbagai turunannya, diakui masih kurang tersentuh dinas-dinas terkait.

\section{Rekomendasi}

- Pengukuran pengetahuan kesehatan reproduksi, meskipun memiliki keterbatasan dengan hanya 10 item pertanyaan, menunjukkan bahwa

- BKKBN dan dinas-dinas yang berkepentingan terhadap diseminasi informasi kesehatan reproduksi sebaiknya melaksanakan evaluasi terhadap media yg digunakan untuk kegiatan sosialisasi pesan kesehatan reproduksi remaja agar dalam menentukan media sesuai dengan kebutuhan masyarakat.

- Penentuan media untuk komunikasi kesehatan reproduksi dapat dikonsetrasikan pada platform-platform online, khususnya Instagram dan Youtube, dengan menggunakan infografis, meme, dan video. Koran dan 
Radio dirasa sudah tidak efektif oleh remaja, dapat diabaikan untuk penyampaian pesan pada segmen remaja.

- Temuan terkait masih kurang optimalnya pengetahuan informasi kesehatan reproduksi remaja, perlu mendapatkan perhatian di level kebijakan baik di BKKBN maupun kelembagaan terkait seperti Dinkes, Diskominfo, dan Dinas Pendidikan. Mendorong konten kesehatan reproduksi sebagai bagian dari kurikulum Pendidikan, bisa menjadi solusi.

\section{REFERENSI}

Azwar, Saifuddin. 2013. Metode Penelitian . Yogyakarta: Pustaka Pelajar.

Alderfer, C. P. 1972. Existence, relatedness, and growth. New York: Free Press.

Blumler, J. G., \& Katz, E. 1974. The uses of mass communications: Current perspectives on gratifications research. Beverly Hills, CA: Sage

Brown J. D., Kelly L., Pardun C. J., Guo G., Kenneavy K., and Jackson C.. 2006. Sexy Media Matter, Exposure to Sexual Content in Music, Movies, Television, and Magazines Predicts Black and White Adolescents Sexual Behavior. Pediatrics.[internet]. Pediatrics, DOI. 10. 1542/1081: 1018-1027. http://pediatrics.org/cgi/doi/10.1542/ped $\mathrm{s}$

Bungin B.. 2009. Sosiologi Komunikasi (Teori, Paradigma, dan Diskursus Teknologi Komunikasi di Masyarakat). Jakarta: Kencana Prenada Media Group.

Cangara H. 2009. Pengantar Ilmu Komunikasi. Jakarta: PT. Raja Grafindo.

Hernandez R. E. 2007.Remaja dan Media. Bandung: Pakar RayaMonks K. J. 2002. Psikologi Perkembangan. Yogyakarta: Gajah Mada University Press.

Gunarsa S. D., Gunarsa Y. 2003. Psikologi Anak dan Remaja. Jakarta: BPK Gunung Mulia.

Ivanov, Michael. Werner, Paul D. 2010. Behavioral communication: Individual differences in communication style.
Personality and Individual Differences. 49: 19-23.

Katz, E., Blumler, J. G., \& Gurevitch, M. 1973. Uses and gratifications research. The Public Opinion Quarterly, 37(4), 509-523.

Levy, M. R., \& Windahl, S. 1984. Audience activity and gratifications. A conceptual clarification and exploration. Communication Research, 11(1), 51-78.

Maslow, A. H. 1954. Motivation and personality. New York, NY: Harper \& Row.

Maslow, A. H. 1970. Motivation and personality (2nd ed., Rev.). New York, NY: Harper and Row.

Notoatmodjo, Soekidjo. 2003. Pendidikan Dan Perilaku Kesehatan. Jakarta: Rineka Cipta

Santrock, J.W. (2003) Adolescence, Perkembangan Remaja. Jakarta: PT. Erlangga.

Sarwono, Sarlito Wirawan (2010). Psikologi Remaja (Edisi Revisi). Jakarta: PT. Raja Gravido Persada

Susanto. 2013. Hubungan Antara Sikap terhadap Media Pronografi dengan Perilaku Seksual Pranikah pada Remaja. Jurnal Fakultas Psikologi "Empathy" Universitas Ahmad Dahlan edisi 2013. Jogjapress. Yogyakarta

Sugiyono. 2011. Metode Penelitian Kuantitatif, Kualitatif dan R\&D. Bandung: Afabeta.

Syuderajat \& Rachman. 2014. Perilaku Seksual Remaja dan Penggunaan Internet Pada Salah Satu Perguruan Tinggi di Jatinangor, Sumedang, Jawa Barat. Universitas Padjadjaran. Jatinangor.

Thoha, Miftah. Perilaku organisasi. Jakarta: Rajawali.

Vivian, John. 2008. Teori Komunikasi Massa. Jakarta: Kencana 